\title{
Seasonal survey of the composition and degradation state of particulate organic matter in the Rhône River using lipid tracers
}

\author{
M.-A. Galeron ${ }^{1}$, R. Amiraux ${ }^{1}$, B. Charriere ${ }^{2}$, O. Radakovitch $^{3}$, P. Raimbault ${ }^{1}$, N. Garcia ${ }^{1}$, V. Lagadec ${ }^{1}$, F. Vaultier ${ }^{1}$, \\ and J.-F. Rontani ${ }^{1}$ \\ ${ }^{1}$ Aix-Marseille University, Mediterranean Institute of Oceanography (MIO), 13288, Marseille, CEDEX 9; Université du Sud \\ Toulon-Var, 83957, CNRS-INSU/IRD UM 110, France \\ ${ }^{2}$ Centre de Formation et de Recherche sur l'Environnement Méditerranéen (CEFREM, UMR CNRS 5110), Bât. U, \\ Université de Perpignan, Via Domitia (UPVD), 66860 Perpignan, France \\ ${ }^{3}$ CEREGE UM34, Aix Marseille Université, CNRS, IRD, CDF, 13545 Aix-en-Provence, France
}

Correspondence to: M.-A. Galeron (marie-aimee.galeron@mio.osupytheas.fr)

Received: 1 September 2014 - Published in Biogeosciences Discuss.: 2 October 2014

Revised: 9 January 2015 - Accepted: 28 January 2015 - Published: 5 March 2015

\begin{abstract}
Lipid tracers including fatty acids, hydroxyacids, $n$-alkanols, sterols and triterpenoids were used to determine the origin and fate of suspended particulate organic matter (POM) collected in the Rhône River (France). This seasonal survey (April 2011 to May 2013) revealed a yearround strong terrestrial higher-plant contribution to the particulate organic matter (POM), with significant algal inputs observed in March and attributed to phytoplanktonic blooms likely dominated by diatoms. Major terrigenous contributors to our samples are gymnosperms, and more precisely their roots and stems, as evidenced by the presence of high proportions of $\omega$-hydroxydocosanoic acid (a suberin biomarker). The high amounts of coprostanol detected clearly show that the Rhône River is significantly affected by sewage waters.

Specific sterol degradation products were quantified and used to assess the part of biotic and abiotic degradation of POM within the river. Higher-plant-derived organic matter appears to be mainly affected by photo-oxidation and autoxidation (free radical oxidation), while organic matter of mammal or human origin, evidenced by the presence of coprostanol, is clearly more prone to bacterial degradation. Despite the involvement of an intense autoxidation-inducing homolytic cleavage of peroxy bonds, a significant proportion of hydroperoxides is still intact in higher plant debris. These compounds could affect the degradation of terrestrial material by inducing an intense autoxidation upon its arrival at sea.
\end{abstract}

\section{Introduction}

With an average water discharge of $1700 \mathrm{~m}^{3} \mathrm{~s}^{-1}$ (Ludwig et al., 2009), the Rhône is the main freshwater contributor to the Mediterranean Sea. Based on various studies, the mean annual flux of suspended matter is about $6.7 \times 10^{6} \mathrm{t} \mathrm{yr}^{-1}$ over the period 1967-2008 (Eyrolle et al., 2012), and the annual particulate organic carbon (POC) flux was estimated to be $1.94 \pm 1.09 \times 10^{5} \mathrm{tyr}^{-1}$ (Sempéré et al., 2000). The labile POC fraction, calculated as the carbon contribution from sugars and amino acids to Total POC, was estimated to be between 3 and $27 \%$ depending on the amount of SPM (Sempéré et al., 2000). The Rhône River represents 14 and $10 \%$ of fresh water and particulate carbon input to the Mediterranean Sea, respectively (Ludwig et al., 2009). Given the importance of such a contribution, it is crucial to study the provenance and composition of the organic matter found in the Rhône, prior to its arrival in the Mediterranean Sea.

Up until recently, it was widely considered that the terrestrial particulate organic matter (TPOM) flowing into oceans through rivers was refractory to degradation (biotic and abiotic), since it was constituted of terrestrial plant debris previously degraded during transport (de Leeuw and Largeau, 1993; Wakeham and Canuel, 2006). However, coastal sediments have shown very little trace of a terrestrial OM signature (Hedges and Keil, 1995; McKee et al., 2004), which implies that either global carbon fluxes and budgets are wrong, or, as is more likely, that terrestrial POM undergoes a rapid 
and intense degradation upon its arrival at sea (Hedges et al., 1997). The belief that terrestrial POM is refractory to all sorts of decomposition has been recently challenged through studies in the Mediterranean Sea (Bourgeois et al., 2011) and northern Canada (Rontani et al., 2014b), showing that wellpreserved TPOM is heavily degraded upon leaving river systems. This is why we intend to study the chemical structure and degradation state of TPOM in the Rhône River, in order to better understand how such an intense degradation can be possible at sea, while it was not during freshwater transport.

In comparison with bulk geochemical analyses, where $\delta^{13} \mathrm{C}$ terrestrial end-member determination is precarious, $\delta^{13} \mathrm{C}$ signatures of organic matter at a molecular level can be more specific (Tolosa et al., 2013). Unfortunately, carbon isotopic data in freshwater ecosystems is not always source-specific, because freshwater phytoplankton and terrestrial plants can often produce similar $\delta^{13} \mathrm{C}$ signatures (Cloern et al., 2002). Many studies used biomarkers such as lipids, cutins or waxes in sediment or soil samples in order to determine the specific contribution of plants in organic matter (Amelung et al., 2008; Simpson et al., 2008). Sterols (steroidal alcohols) have specific structural features that can be linked to a restricted number of organisms (Volkman, 1986), and can be used to determine the main contributors to a pool of organic matter. Their degradation products, such as stanols, 3,6-diols, or triols, can also inform on the type of degradation undergone (Christodoulou et al., 2009; Rontani et al., 2009). On the other hand, cuticular waxes and cutins can be linked to relatively specific higher plant groups (Mueller et al., 2012), allowing an estimation of the contribution of terrestrial plants to the OM.

There are no studies dealing with the composition of the plant-derived particulate organic matter carried along the Rhône River in the literature. We propose to confirm the hypothesis according to which the POM sampled in the Rhône is mainly constituted of terrestrially produced organic matter traveling with the runoff, while also identifying other sources of OM, sometimes significantly aquatic/planktonic. Although limited research has been done on freshwater plankton dynamics in the Rhône, it has been found that phytoplankton communities in the middle Rhône suffer a high turnover (Fruget et al., 2001) implying an important potamoplankton input in the particulate organic matter flowing down the river.

Using specific lipids and their degradation products, here we report for the first time on the different sources of OM in the Rhône River and discuss the main degradation processes affecting this OM.

\section{Materials and methods}

\subsection{Study area and sampling}

The Rhône River is $816 \mathrm{~km}$ long and has a drainage area of $97800 \mathrm{~km}^{2}$ (Fig. 1). The Rhône being a river prone to seasonal flooding, our samples span a wide range of water flow conditions in order to be as representative as possible (Fig. 2).

To monitor temporal variations of suspended particulate matter (SPM), POC, nutrients and lipidic biomarkers in the Rhône River, 30 surface water and particle samples were collected between April 2011 and May 2013 at the Rhône River reference riverine station of Arles, $40 \mathrm{~km}$ upstream from the river mouth (Fig. 1).

The high-frequency study of the nutrients and particulate matter input by the Rhône to the Mediterranean Sea has been carried out since 2010 in the framework of the national program MOOSE (Mediterranean Ocean Observing System for the Environment). Monitoring was undertaken at the Arles station (Fig. 1). Sampling included filtering between 100 and $400 \mathrm{~mL}$ of water on $\mathrm{GF} / \mathrm{F}$ glass fiber filters, as well as particles collection using a high-speed centrifuge device (CEPA Z61) coated with teflon to avoid metal contamination. For suspended matter determination, water samples were filtered on pre-weighted GF/F filters. After drying, filters were weighted to determine the suspended particulate matter (SPM) content (in $\mathrm{mg} \mathrm{L}^{-1}$ ). Non-weighted filters were used to quantify Particulate Organic Carbon (POC) contents: the filters were acidified with $50-100 \mu \mathrm{L} 0.5 \mathrm{~N}$ sulfuric acid and dried overnight at $60^{\circ} \mathrm{C}$ (Raimbault et al., 1999). POC contents were determined using a high-combustion $\left(900^{\circ} \mathrm{C}\right)$ procedure on a CN Integra mass spectrometer (Sercon). Filtrates were used to analyze inorganic nutrients (nitrate, nitrite, phosphate) using the automated colorimetric method described in Aminot and Kérouel (2007), while samples for silicate analysis were filtrated through a $0.45 \mu \mathrm{m}$ polycarbonate membrane and kept at $5^{\circ} \mathrm{C}$ until analysis. Uncertainty of SPM is estimated to be $0.05 \mathrm{mg} \mathrm{L}^{-1}$ while the analytical error for POC determination is $5 \mu \mathrm{M}$ (both errors were calculated during method validation, using replicates, and take into account scale and spectrometer precision and detection limits). Chlorophyll concentration was quantified using methanol extraction according to Raimbault et al. (2004). Samples (filters, filtrates and particles) were immediately frozen at $-20^{\circ} \mathrm{C}$ until analysis.

\subsection{Chemical treatment of the samples}

Prior to analysis all samples were thawed and their water content was measured through the weighting of humid versus oven-dried particles: dry particles $(\mathrm{g}) /$ humid particles $(\mathrm{g}) \times 100$. The suspended particles collected (between 200 and $450 \mathrm{mg}$ per sample) first needed to be reduced with $\mathrm{NaBH}_{4}$ and saponified. $\mathrm{NaBH}_{4}$-reduction of hydroperoxides 


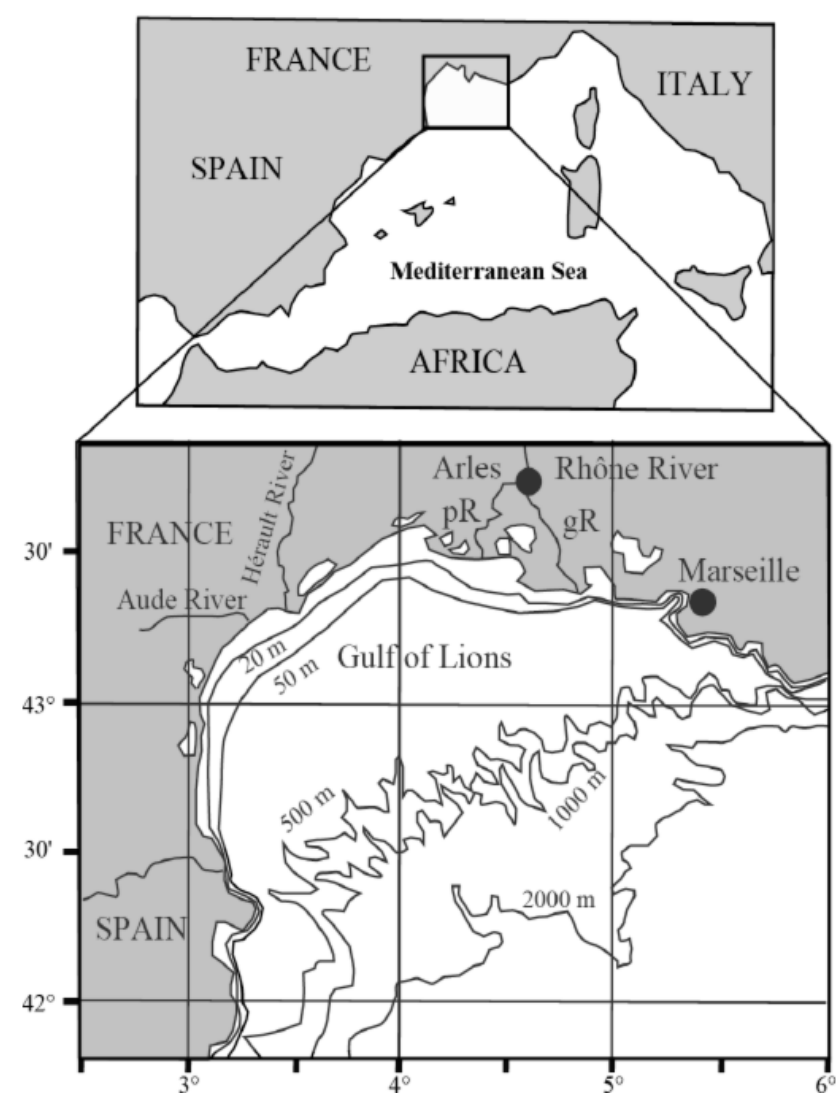

Figure 1. Rhône River mouth area and sampling location: "Arles". $\mathrm{gR}$ and $\mathrm{pR}$ denote grand Rhône and petit Rhône which are the two arms of the river.

to alcohols that are amenable to gas chromatography electron impact mass spectrometry (GC-EIMS) is essential for estimating the importance of photo-oxidative and autoxidative degradation in natural samples (Marchand and Rontani, 2001). Without this preliminary treatment, these labile compounds can be thermally cleaved during alkaline hydrolysis or GC analysis and thus be overlooked during conventional organic geochemical studies. Lipids and their degradation products in the resulting total lipid extracts (TLEs) were then quantified by GC-EIMS. All manipulations were carried out using foil-covered vessels in order to exclude photochemical artifacts. It is well known that metal ions can promote autoxidation during hot saponification (Pokorny, 1987). The prior reduction of hydroperoxides with $\mathrm{NaBH}_{4}$ allowed us to avoid such autoxidation artifacts during the alkaline hydrolysis.

Particles were placed in methanol $(\mathrm{MeOH})(15 \mathrm{~mL})$ and hydroperoxides were reduced to the corresponding alcohols with excess $\mathrm{NaBH}_{4}\left(70 \mathrm{mg} ; 30 \mathrm{~min}\right.$ at $\left.20^{\circ} \mathrm{C}\right)$. During this treatment, ketones are also reduced and the possibility of some ester cleavage cannot be excluded.

Saponification was carried out on reduced samples. After $\mathrm{NaBH}_{4}$ reduction, $15 \mathrm{~mL}$ water and $2.24 \mathrm{~g} \mathrm{KOH}$ were added and the mixture directly saponified by re-

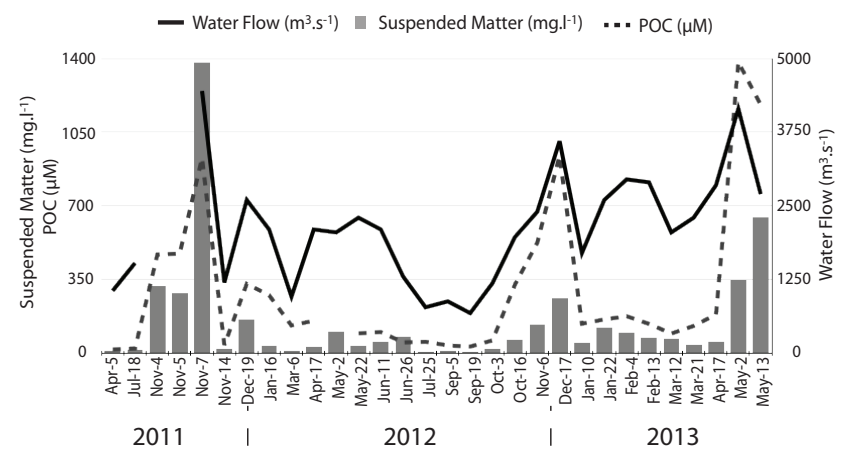

Figure 2. Water flow $\left(\mathrm{m}^{3} \mathrm{~s}^{-1}\right)$, suspended particulate matter $\left(\mathrm{mg} \mathrm{L}^{-1}\right)$ and particulate organic carbon (POC, $\left.\mu \mathrm{M}\right)$ of Rhône waters on our sampling dates (MOOSE data). Samples span a wide range of water flow conditions.

fluxing for $2 \mathrm{~h}$. After cooling, the content of the flask was acidified with $\mathrm{HCl}(\mathrm{pH} 1)$ and extracted $(3 \times)$ with dichloromethane (DCM). The combined DCM extracts were concentrated to give the TLE. After solvent evaporation, residues were taken up in $300 \mu \mathrm{L}$ of pyridine $/ N, O$ bis(trimethylsilyl)trifluoroacetamide (BSTFA; Supelco; 2 : $1, v: v)$ and silylated for $1 \mathrm{~h}$ at $50^{\circ} \mathrm{C}$ to convert $\mathrm{OH}-$ containing compounds to TMSi-ether or ester derivatives. After evaporation to dryness under a stream of $\mathrm{N}_{2}$, the derivatized residues were taken up in $100 \mu \mathrm{L}$ BSTFA (to avoid desilylation of fatty acids) and an appropriate amount of ethyl acetate, depending on the concentration in lipids in each sample, in order to get the best possible GC-EIMS reading. It should be noted that under these conditions steran- $3 \beta, 5 \alpha, 6 \beta$ triols were silylated only at $\mathrm{C} 3$ and C6 and thus need to be analyzed with great care (Rontani et al., 2014b).

A different treatment was used to quantify hydroperoxides and their ketonic and alcoholic degradation products. The samples were extracted three times with chloroform-MeOH$\mathrm{H}_{2} \mathrm{O}(1: 2: 0.8, v: v: v)$ using ultrasonication. The supernatant was separated by centrifugation at $3500 \mathrm{G}$ for $9 \mathrm{~min}$. To initiate phase separation, purified $\mathrm{H}_{2} \mathrm{O}$ was added to the combined extracts to give a final volume ratio of $1: 1(v: v)$. The upper aqueous phase was extracted three times with DCM and the combined DCM extracts were filtered and the solvent removed via rotary evaporation. The residue obtained after extraction was dissolved in $4 \mathrm{~mL}$ of DCM and separated in two equal subsamples. After evaporation of the solvent, degradation products were obtained for the first subsample after acetylation (inducing complete conversion of hydroperoxides to the corresponding ketones, Mihara and Tateba, 1986) and saponification and for the second after reduction with $\mathrm{NaBD}_{4}$ and saponification. Comparison of the amounts of alcohols present after acetylation and $\mathrm{NaBD}_{4}$ reduction made it possible to estimate the proportion of hydroperoxides and alcohols present in the samples, while after $\mathrm{NaBD}_{4}$-reduction deuterium labeling allowed us to esti- 
mate the proportion of ketones really present in the samples (Marchand and Rontani, 2003).

\subsection{GC-EIMS analyses}

Lipids and their oxidation products were quantified using an Agilent 7850-A gas chromatograph connected to an Agilent 7000-QQQ mass spectrometer. The following conditions were employed: $30 \mathrm{~m} \times 0.25 \mathrm{~mm}$ (i.d.) fused silica column coated with HP-5MS (Agilent; film thickness: $0.25 \mu \mathrm{m}$ ); oven programmed from 70 to $130^{\circ} \mathrm{C}$ at $20^{\circ} \mathrm{C} \mathrm{min}^{-1}$, then to $250^{\circ} \mathrm{C}$ at $5^{\circ} \mathrm{C} \mathrm{min}^{-1}$ and then to $300^{\circ} \mathrm{C}$ at $3^{\circ} \mathrm{C} \mathrm{min}^{-1}$; carrier gas (He), 1.0 bar; injector (splitless), $250^{\circ} \mathrm{C}$; injector (on column), $50^{\circ} \mathrm{C}$; electron energy, $70 \mathrm{eV}$; source temperature, $230^{\circ} \mathrm{C}$; quadrupole temperature, $150^{\circ} \mathrm{C} ; \mathrm{m} / z$ 40700; collision energy, ranging from 5 to $15 \mathrm{eV}$; collision flow, $1.5 \mathrm{~mL} \mathrm{~min}^{-1}\left(\mathrm{~N}_{2}\right)$; quench flow, $2.25 \mathrm{~mL} \mathrm{~min}^{-1}(\mathrm{He})$; cycle time, $0.2 \mathrm{~s}$. An on-column injector was used for the analysis of sterol degradation products and a splitless injector for the analysis of FA degradation products. Compounds were assigned by comparison of retention times and mass spectra with those of standards and quantified (calibration with external single standards) with GC-EIMS. For low concentrations, or in the case of co-elutions, quantification was achieved using selected ion monitoring (SIM) or multiple reaction monitoring (MRM). The main characteristic mass fragment ions used to quantify degradation products of sterols have been described previously (Christodoulou et al., 2009; Rontani et al., 2011). Using replicates, the analytical standard error for lipid quantification (from preparation to integration) was estimated to be $14 \%$ (Standard Error = Standard Deviation / $\sqrt{ }(n)$ for $n$ replicates).

\section{Results and discussion}

\subsection{Water discharge, suspended particulate matter (SPM) and particulate organic carbon (POC)}

Water flow patterns in the Rhône show pronounced seasonal variations predominantly influenced by three factors that can induce maximum discharge (Vivian, 1989): snow melting (May-June), intense rains in the south basin (OctoberNovember) and rains over the entire basin (January-March). During our sampling period the daily flow rate fluctuated between 680 (19 September 2012) and $4661 \mathrm{~m}^{3} \mathrm{~s}^{-1}$ (5 November 2011; Fig. 2). Suspended particulate matter (SPM) and POC concentrations (Fig. 2) ranged from 6.5 to $1381.3 \mathrm{mg} \mathrm{L}^{-1}$ and from 17.9 to $1383.3 \mu \mathrm{MC}$, respectively.

The temporal evolution of SPM clearly followed the same pattern as water discharge (Fig. 2), which is typical for river systems (Jansson, 1982). The samples collected on flood dates (November 2011, May 2013, liquid discharges above $3000 \mathrm{~m}^{3} \mathrm{~s}^{-1}$ ) display the highest SPM content and POC values (Fig. 2). POC expressed as a percentage of SPM ranged from 0.8 to $11.6 \%$, and tends to be lower when water flows are highest (Sempéré et al., 2000)

\subsection{Use of lipid tracers to estimate the composition and origin of POM collected in the Rhône River}

\subsubsection{Sterols}

Based on a literature review, cholest-5-en-3 $\beta$-ol (cholesterol), 24-ethylcholest-5-en-3 $\beta$-ol (sitosterol if the C24 stereochemistry is $24 \alpha$ ), cholesta-5,24-dien-3 $\beta$-ol (desmosterol), 24-methylcholesta-5,24(28)-dien-3 $\beta$-ol (24methylenecholesterol), 24-methylcholesta-5,22-dien-3 $\beta$-ol (brassicasterol and/or epi-brassicasterol depending on C-24 stereochemistry) and 24-methylcholest-5-en-3 $\beta$-ol (campesterol) have been selected as tracers of the origin of POM. Apart from cholesterol, which can originate from a wide number of sources, all the other quantified sterols are relatively source-specific. Sitosterol constitutes the major sterol in higher plants, even though it can also be found in diatoms (Volkman, 1986), and is often used to trace terrestrial organic matter in lacustrine and marine systems (e.g., Meyers and Ishiwatari, 1993). Desmosterol is mainly found in algae (Volkman, 1986). 24-Methylenecholesterol is mainly found in diatoms, more particularly in the Thalassiosira and Skeletonema genera in the marine realm (Volkman, 2003). Epi-brassicasterol is mostly found in algae (Volkman, 1986).

All samples are dominated by sitosterol and cholesterol, with proportions being on average 3 times higher than those of the other sterols, apart from the 6 March 2012 sample (Table 1). This sample exhibits a rather different profile, dominated by desmosterol $\left(0.122 \mu \mathrm{g} \mathrm{mg}^{-1}\right.$ (dry weight)) and 24methylenecholesterol $\left(0.096 \mu \mathrm{g} \mathrm{mg}^{-1}\right.$ (dry weight)), with a strong contribution from brassicasterol $\left(0.026 \mu \mathrm{g} \mathrm{mg}^{-1}\right.$ (dry weight)) compared to all other samples. All these sterols have been considered to be planktonic markers, and have been summed to compose the planktonic sterol fraction shown in Fig. 3a. This fraction forms the major part of the total sterol fraction of the March 2012 sample, evidencing a phytoplanktonic bloom event. Given the nature of the sterols involved (desmosterol, methylene-cholesterol), diatoms seem to be major contributors (Rampen et al., 2010). This concurs with the drops in silica observed at the same period (MOOSE data, unpublished). As we see an increase, although less important in the proportion of planktonic sterols in the Spring 2013 samples (20 times less in quantity when compared to the 6 March 2012 sample, but still constituting 31 and $27 \%$ of the total of all sterols quantified in the 12 and 21 March 2013 samples respectively), this type of planktonic event is probably a yearly spring occurrence but our sampling frequency was not adapted to study blooms that can appear and disappear in a matter of days. Sitosterol has been previously identified in marine algae, and more widely as the major sterol in higher terrestrial plants (Volkman, 1986, 
Table 1. Percentages of sterols (relative to the sum of sterols quantified), and sitosterol : campesterol ratio in the samples investigated.

\begin{tabular}{|c|c|c|c|c|c|c|c|}
\hline Date & Sitosterol & Cholesterol & Desmosterol & Brassicasterol & $\begin{array}{l}\text { Methylene- } \\
\text { Cholesterol }\end{array}$ & Campesterol & $\begin{array}{r}\text { Sitosterol: } \\
\text { Campesterol ratio }\end{array}$ \\
\hline 5 April 2011 & 74.4 & 12.7 & 0.4 & 4.9 & 1.2 & 6.4 & 11.6 \\
\hline 18 July 2011 & 21.2 & 45.5 & 2.6 & 16.1 & 3.3 & 11.3 & 1.9 \\
\hline 4 November 2011 & 54.1 & 23.8 & 1.9 & 10.0 & 2.2 & 8.0 & 6.7 \\
\hline 5 November 2011 & 60.2 & 21.4 & 1.2 & 7.7 & 1.7 & 7.9 & 7.6 \\
\hline 7 November 2011 & 56.7 & 28.6 & 0.4 & 6.1 & 1.3 & 6.9 & 8.2 \\
\hline 14 November 2011 & 34.6 & 45.7 & 0.9 & 10.0 & 1.5 & 7.4 & 4.7 \\
\hline 19 December 2011 & 52.5 & 29.1 & 0.5 & 7.5 & 1.9 & 8.5 & 6.2 \\
\hline 16 January 2012 & 39.2 & 43.6 & 1.3 & 6.7 & 1.8 & 7.4 & 5.3 \\
\hline 6 March 2012 & 17.6 & 12.4 & 28.8 & 6.2 & 22.6 & 12.4 & 1.4 \\
\hline 17 April 2012 & 36.5 & 39.3 & 4.7 & 8.2 & 2.9 & 8.4 & 4.4 \\
\hline 2 May 2012 & 38.4 & 41.4 & 2.1 & 9.5 & 1.9 & 6.7 & 5.7 \\
\hline 22 May 2012 & 32.5 & 43.6 & 4.4 & 10.3 & 2.6 & 6.5 & 5.0 \\
\hline 11 June 2012 & 35.0 & 43.5 & 2.5 & 9.6 & 1.6 & 7.7 & 4.5 \\
\hline 26 June 2012 & 24.7 & 54.9 & 2.6 & 10.0 & 1.8 & 6.0 & 4.1 \\
\hline 25 July 2012 & 21.6 & 37.5 & 3.9 & 20.8 & 4.4 & 11.7 & 1.8 \\
\hline 5 September 2012 & 22.6 & 46.6 & 3.4 & 15.4 & 3.3 & 8.6 & 2.6 \\
\hline 19 September 2012 & 21.1 & 44.3 & 3.8 & 19.1 & 3.0 & 8.7 & 2.4 \\
\hline 3 October 2012 & 27.4 & 46.7 & 2.3 & 11.9 & 1.9 & 9.8 & 2.8 \\
\hline 16 October 2012 & 42.9 & 38.9 & 1.4 & 7.8 & 1.4 & 7.6 & 5.7 \\
\hline 6 November 2012 & 44.9 & 36.9 & 2.0 & 7.3 & 1.8 & 7.1 & 6.3 \\
\hline 17 December 2012 & 66.3 & 22.8 & 1.0 & 3.5 & 1.2 & 5.2 & 12.7 \\
\hline 10 January 2013 & 46.9 & 34.8 & 2.5 & 7.1 & 1.5 & 7.2 & 6.5 \\
\hline 22 January 2013 & 36.0 & 48.4 & 1.4 & 6.9 & 1.3 & 6.1 & 5.9 \\
\hline 4 February 2013 & 50.0 & 39.2 & 0.8 & 4.0 & 0.8 & 5.1 & 9.8 \\
\hline 13 February 2013 & 55.4 & 30.7 & 2.0 & 4.8 & 1.3 & 5.9 & 9.4 \\
\hline 12 March 2013 & 35.1 & 27.6 & 14.5 & 9.0 & 7.6 & 6.2 & 5.7 \\
\hline 21 March 2013 & 37.4 & 29.0 & 11.1 & 8.9 & 6.6 & 7.2 & 5.2 \\
\hline 17 April 2013 & 35.6 & 45.6 & 2.6 & 7.0 & 2.5 & 6.7 & 5.3 \\
\hline 2 May 2013 & 59.0 & 24.5 & 1.1 & 6.8 & 1.7 & 6.8 & 8.7 \\
\hline 13 May 2013 & 49.7 & 38.6 & 0.0 & 4.6 & 1.1 & 6.1 & 8.2 \\
\hline Average & 41.0 & 35.9 & 3.6 & 8.9 & 3.0 & 7.6 & 5.9 \\
\hline SD & 14.6 & 10.7 & 5.6 & 4.2 & 4.0 & 1.8 & 2.8 \\
\hline
\end{tabular}

2003). However, the clear increase observed here in March 2012 demonstrates that it is also present in potamoplankton (Fig. 3a). The presence of cholesterol can indicate a zooplankton contribution (Volkman, 1986), but it is also often found in freshwater algae (Volkman et al., 1981; Gagosian et al., 1983), and can also evidence human impacts (Sicre et al., 1993). The relatively high proportions of $5 \beta(\mathrm{H})$-cholestan$3 \beta$-ol (coprostanol) detected in the samples investigated (see Sect. 3.3.2) clearly show that in the Rhône River cholesterol mainly arises from waste water inputs (Brown and Wade, 1984).

We also looked at the ratio sitosterol / campesterol (Table 1) as an indicator of the terrigenous versus diatom origin of our POM. While many plants have a sitosterol / campesterol ratio of less than 4 (Volkman, 1986), Nishimura and Koyama (1977) reported values ranging from 11.5 (Pinus densiflora) to 31 (hollyIlex pedunculosa). Dachs et al. (1998) identified the threshold of 1 as the limit under which samples are dominated by $\mathrm{OM}$ of aquatic ori- gin, and above which sources of OM are terrigenous. In our case, all the samples present a sitosterol / campesterol ratio above 1, mainly between 2 and 8 (up to 12). Three samples show a ratio near 1 (July 2011 and 2012 and March 2012; Table 1), a low value which confirms the presence of diatoms in the plankton since freshwater diatoms exhibit sitosterol / campesterol ratios close to 1.0 (Ponomarenko et al., 2004).

\subsubsection{Terrestrial vascular plant biomarkers}

The contribution of terrestrial vascular plants to our samples is also evidenced by the presence of the triterpenoids betulin (lup-20(29)-ene-3 $\beta, 28$-diol), oleanolic ( $3 \beta$-hydroxyolean12 -en-28-oic) and ursolic (3 $\beta$-hydroxyurs-12-en-28-oic) acids (Razboršek et al., 2008) as well as components of cuticular waxes (16,8-11-dihydroxyhexadecanoic, $\omega$-hydroxyhexadecanoic, $\omega$-hydroxyoleic and 18hydroxyoctadec-9-enoic acids) (Kolattukudy, 1980) 

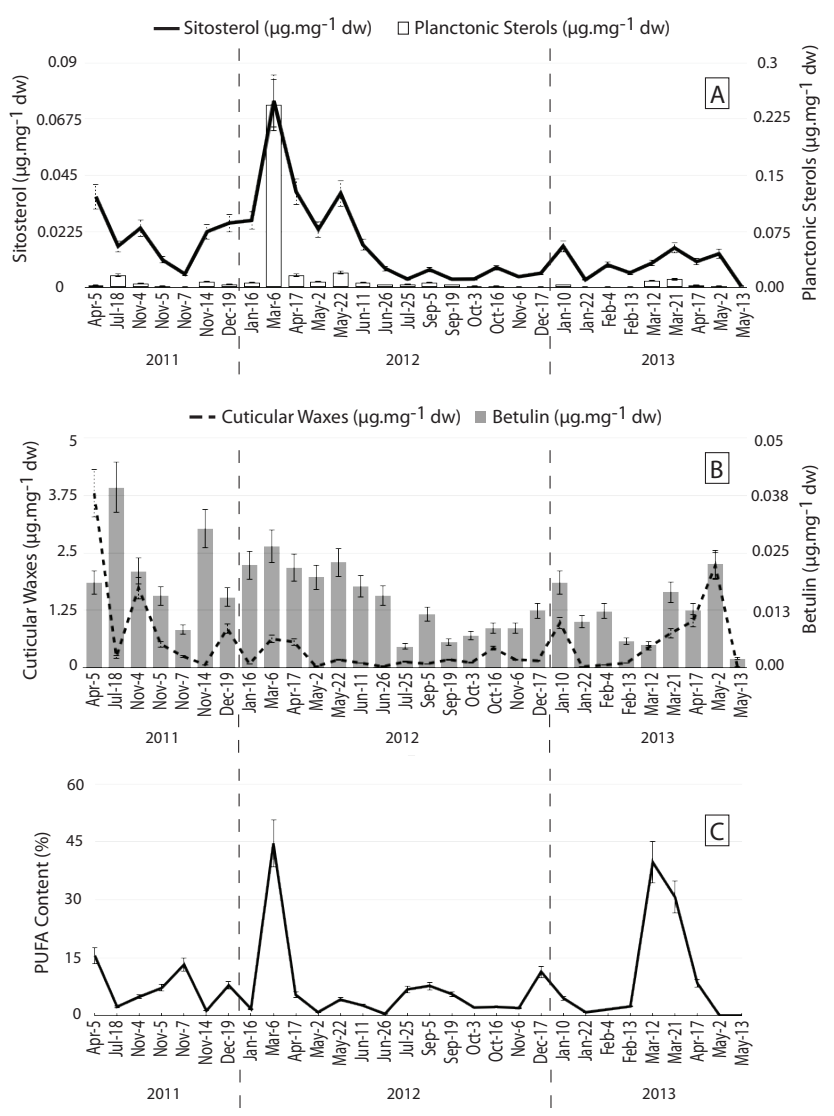

Figure 3. Sitosterol and planktonic sterols (a), cuticular waxes and betulin (b) and poly-unsaturated fatty acid (PUFA) (c) contents of the different samples. Standard error shown was estimated to be $14 \%$ (see Sect. 2.3). Phytoplanktonic blooms are evidenced by the spike in planktonic sterols, and while the other tracers show the terrigenous origin of the POM sampled, the ubiquitous nature of sitosterol is made clear.

(Fig. 3b). Betulin has been proposed as a tracer for paper birch (Fine et al., 2001), a common species along the Rhône River, while oleanolic and ursolic acids are widely distributed in terrestrial higher plants (Liu, 1995). The amount of cuticular waxes is variable amongst samples, between 0.02 and $3.8 \mu \mathrm{g} \mathrm{mg}^{-1}$ (dry weight), with the highest in the 5 April 2011, 2 May 2013 and 4 November 2011 samples $\left(3.8,2.2\right.$ and $1.7 \mu \mathrm{g} \mathrm{mg}^{-1}$ respectively). Two of these sample dates (2 May 2013 and 4 November 2011) happen to be flood dates. It is clear that floods, during which higher water flows are coupled to surface runoff, collect and carry more terrestrial plant leaf debris, and hence increase the amount of cuticular waxes found in our samples. The yearly variations in quantity are probably due to the fact that waxes (linear compounds) are more easily degraded by bacteria than cyclic structures such as sterols or triterpenoids (Atlas and Bartha, 1992).

The betulin and sitosterol concentrations are significantly correlated in most of our samples ( $r=0,67$ between sitos- terol and betulin, on 29 samples, $p$-value $=3.10^{-5}$, excluding the 6 March 2012 sample due to its out-of-range phytoplanktonic profile), thus reinforcing the idea that in the Rhône River sitosterol mainly results from terrestrial higher plant inputs. However, at the time of the spring bloom a significant part of this sterol seems to derive from potamoplankton (Fig. 3b).

Another ratio commonly used to attest to the terrigenous origin of compounds is the Terrigenous-to-Aquatic ratio (TAR, Bourbonnière and Meyers, 1996). Here we used the $\operatorname{TAR}_{(\mathrm{AL})}$ as calculated by Van Dongen et al. (2008) for $n$ alkanols: $\left(\mathrm{C}_{26}+\mathrm{C}_{28}\right) /\left(\mathrm{C}_{16}+\mathrm{C}_{18}\right)$. The $\mathrm{TAR}_{(\mathrm{AL})}$ in our samples is always above 1 , and clearly indicates a strong terrigenous contribution to the suspended particulate matter found in the lower Rhône. The Average Chain Length of $n$ alkanols, a proxy positively correlated to the abundance of higher plant debris (Van Dongen et al., 2008), ranged from 26 to 22 across all samples, also attesting to the strong contribution of terrestrial vascular plants. The long-chain evennumbered $n$-alkanol profiles show a strong contribution of $\mathrm{C}_{22}$ and $\mathrm{C}_{28} n$-alkanols. Compared with those previously described in the literature (Diefendorf et al., 2011), this characteristic suggests a strong gymnosperm contribution, which concurs with the low amounts of long-chain $n$-alkanes detected.

\subsubsection{Chlorophyll}

The available data on chlorophyll $a$ (MOOSE database, only available for 2012 and 2013) show a content variability between 0.9 (10 October and 6 November, 2012) and 14.0 (3 April 2012) $\mathrm{mg} \mathrm{m}^{-3}$ (Fig. 4a). Chlorophyll $a$ is frequently used as a proxy for photosynthetic organisms and the variation observed here is consistent with the hypothesis of a yearly phytoplanktonic spring bloom, with a larger magnitude for the 2012 event.

\subsubsection{Fatty acids}

A number of saturated linear fatty acids have been found in our samples, with $\mathrm{C}_{16: 0}$ and $\mathrm{C}_{18: 0}$ being the most abundant (Table 2). These fatty acids are not specific, and can stem from a number of sources including terrestrial vascular plants, algae and bacteria (Volkman et al., 1981). More recently. $\mathrm{C}_{16: 1 \omega 7}$ and $\mathrm{C}_{20: 5 \omega 3}$ (eicosapentaenoic acid) were identified as two of the main fatty acids in Bacillariophyceae (Taipale et al., 2013). These two markers are present in our samples, and together form 40.5 and $34.1 \%$ of the 6 March 2012 and 12 March 2013 samples (versus an average of $13.2 \%$ across all samples), which, when coupled with our sterol analysis, concurs with our hypothesis that diatoms are major contributors in the algal blooms identified. It is worth noting that in the 3 October 2012 sample, $\mathrm{C}_{16: 1 \omega 7}$ forms $53.6 \%$ of all quantified fatty acids, while $\mathrm{C}_{20: 5 \omega 3}$ is completely absent $(0 \%)$, and therefore these markers alone can- 


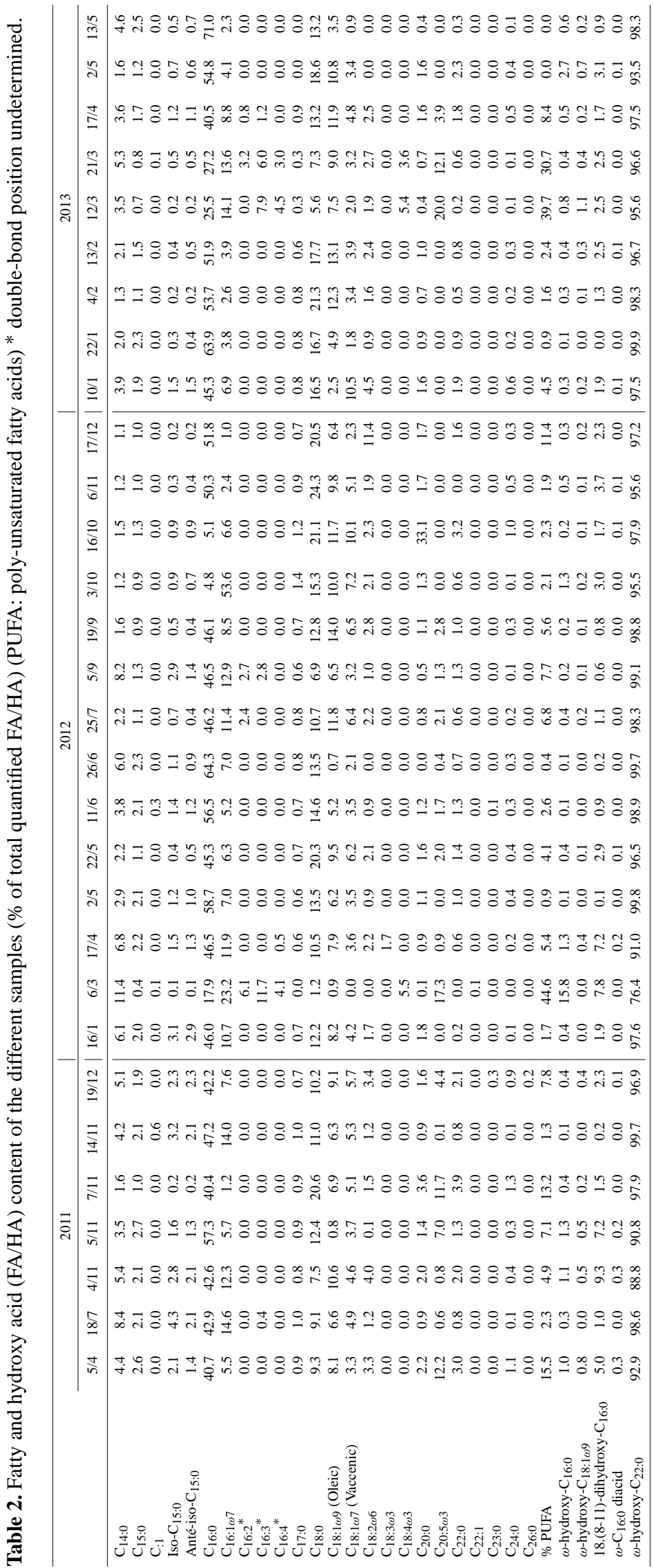



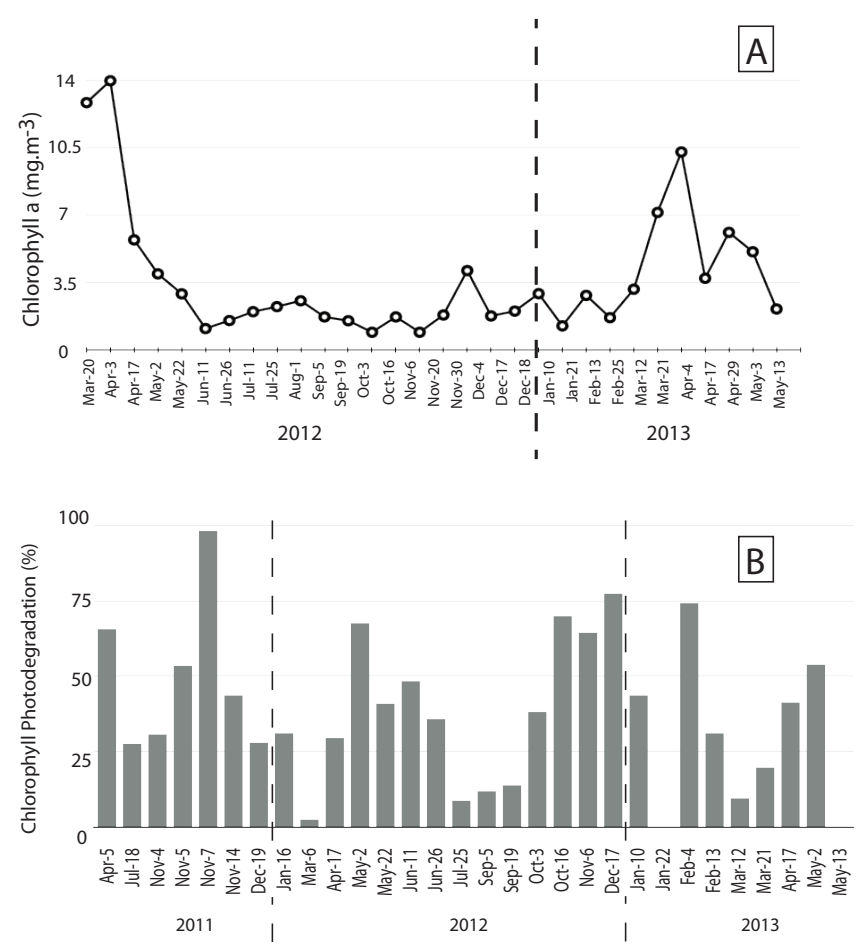

Figure 4. Chlorophyll $a$ levels (MOOSE data) and percentage of photodegradation of chlorophyll, calculated using CPPI (Cuny et al., 1999) in the Rhône waters on and around sample dates.

not be considered to be specific enough in natural river water samples which can contain a number of fatty acids from various sources.

Longer-chain saturated fatty acids (between $\mathrm{C}_{20}$ and $\mathrm{C}_{28}$ ) with a strong even-chain predominance, which are specific to the epicuticular waxes of vascular plants (Kunst and Samuels, 2003), are scarcely present in our samples, with $\mathrm{C}_{20}$ and $\mathrm{C}_{22}$ being the most abundant relative to the others: over $98 \%$ (on average) of the total of long-chain $\left(\mathrm{C}_{20}-\mathrm{C}_{28}\right)$ saturated fatty acids across all samples. Due to the high degradability of fatty acids, a number of them could not be quantified, potentially leading to an underestimation of higher plant contribution.

Polyunsaturated fatty acids are present in very low proportions in our samples, apart from the 6 March 2012 and 12 March 2013 samples where they contributed to 44 and $40 \%$ of total fatty acids (Fig. $3 \mathrm{c}$ - quantified using the total of all PUFA quantified between $\mathrm{C}_{14}$ and $\mathrm{C}_{26}$ ). These high contributions support the presence of a high proportion of fresh algal material in these samples.

If we compare the average chain length (ACL) of fatty acids in our samples with that of $n$-alkanols, it appears clearly that the ACL of fatty acids is lower, with an average of 16.7 across samples, against 23.9 for alcohols. It is widely accepted that fatty acids are more prone to bacterial degradation than other lipids (Wakeham, 1995), and long-chain fatty acids tend to be degraded more efficiently by a number of bacteria (Novak and Carlson, 1970). Such a bacterial degradation could explain the ACL difference between $n$-alkanols and fatty acids, and the lack of terrestrial higher-plant fatty acids in our samples, while other markers for higher plants (such as waxes or betulin) are present in large quantities. This is reinforced by the fact that we also find a relatively high proportion of vaccenic acid in our samples, a specific marker for bacterial activity (Sicre et al., 1988)

\subsubsection{Hydroxyacids}

Hydroxyacid contents were low during the period studied but some samples (18 July 2011, 4 November 2011 and 16 January 2012) exhibited high amounts of $\mathrm{C}_{22} \omega$-hydroxyacid and small quantities of $\mathrm{C}_{20}$ and $\mathrm{C}_{24}$ homologues (Table 2). These compounds are generally considered to be suberin markers when found in soil (Nierop, 1998; Otto et al., 2005), even though they have been found in leaves and stems of higher plants as well (Mendez-Millan et al., 2010). Suberin is a cell wall component of cork cells, and is mainly found in bark, woody stems and roots (Kolattukudy, 1980). Given the geographical location of our sampling point, we can consider this compound to be a marker of industrial activity, probably associated with a paper paste mill less than $3 \mathrm{~km}$ upstream. The mill uses mainly local conifers (collected within a $250 \mathrm{~km}$ radius according to the company, Paper Excellence, 2014), more particularly Pinus halepensis, Pinus nigra, and Pinus sylvestris (Etude AGRESTE, 2011) and is authorized to reject a certain amount of wastewater in the river. This is consistent with our findings that the POM is dominated by gymnosperms. Pinus species also display a sitosterol / campesterol ratio of between 5 and 10 (Conner et al., 1980) in line with most of our samples as well. This industrial contamination could explain the large contribution of gymnosperms to our POM, and implies that we consider the extra input of terrestrial plant matter that will be released, and degraded, at sea.

As a summary, the overall lipid composition of the Rhône River SPM is characterized by major terrestrial higher plant components (mainly derived from gymnosperms) with episodic, but significant, contributions from freshwater algal material (probably dominated by diatoms) in the spring. Despite the strong concentration of industries along this river, SPM appears to be very weakly contaminated by petroleum hydrocarbons, but is strongly impacted by the local paper mill and wastewater discharges (see Sect. 3.2.2).

\subsection{Use of lipid tracers to estimate the degradation state of POM from the Rhône River}

If they can inform us on the origin of organic matter in natural environments, lipid biomarkers are also invaluable in helping us estimate biotic and abiotic alterations of organic matter and determine what are the main processes involved in its degradation. Products resulting from the degradation 
of sterols, chlorophyll, monounsaturated fatty acids and hydroxyacids are among the most useful and specific tracers.

\subsubsection{Chlorophyll}

The absorption of light by some compounds, called photosensitizers, in the presence of oxygen (regardless of these compounds being endogenous or not) causes an oxidation whose effects, chemical or biological, are mostly adverse (Spikes and Straight, 1967). Photosensitizers induce chemical reactions via the absorption of light that would not occur in their absence. Photosensitizers (Sens) are involved in indirect photo-oxidative processes: they have two systems of electronically excited states, ${ }^{1}$ Sens and ${ }^{3}$ Sens. The triplet state is much longer lived than the singlet state, which is the initial product issued from light absorption. Indirect photo-oxidation (photo-sensitized oxidation) can be intense during the senescence of phototrophic organisms (Rontani, 2012) due to the presence of chlorophyll, which is a very efficient photosensitizer (Foote, 1976) capable of generating singlet oxygen particularly reactive towards unsaturated cellular components (Type II photoprocesses). Chlorophyll may be also directly photodegraded by solar light (Nelson, 1993). Direct photodegradation of chlorophyll and Type II photo-oxidation of unsaturated cellular components can be thus considered two competitive photo-processes.

In the photic layer of aquatic environments, photooxidation has long been considered a major degradation process for phytoplankton chlorophyll pigments (Lorenzen, 1967; Vernet, 1991). Since we have no marker stable and specific enough for chlorophyll tetrapyrrolic ring photodegradation, we used the CPPI (Chlorophyll Phytyl side chain Photodegradation Index) for the in situ determination of the rate of photodegradation of chlorophyll (Cuny et al., 1999). Indeed, the photodegradation of the chlorophyll phytyl side chain produces 3-methylidene-7,11,15-trimethylhexadecan1,2-diol (phytyldiol), specific of Type II chlorophyll photodegradation and widespread in the environment (Cuny and Rontani, 1999). The CPPI, (phytyldiol:phytol molar ratio) can be linked, through a mathematical model, to the global quantity of photodegraded chlorophyll (Cuny et al., 1999),

The photodegradation rate of chlorophyll fluctuates greatly (Fig. 4b). The 6 March 2012 and 12 March 2013 samples display very low rates (2.6 and $9.8 \%$ respectively), in line with our identification of planktonic blooms in March 2012 and 2013. Such blooms result in an increase of fresh chlorophyll inputs, with intact phytyl side chains, and thus in a decrease of CPPI. The dips in chlorophyll photodegradation rates can help us identify blooms, or at least periods when the input of chlorophyll is higher. The summer 2012 samples (July and September) also display a low photodegradation rate ranging from 8.8 to $13.9 \%$ while their amount of planktonic sterols increases slightly.

\subsection{2 $\Delta^{5}$-sterols}

$\Delta^{5}$-sterols possess structural features that can be restricted to a limited number of organisms (Volkman, 1986, 2003). Moreover, biotic and abiotic degradation processes result to specific functionalizations of their cyclic skeleton (De Leeuw and Baas, 1986), which are very useful to estimate the relative importance of these processes (Christodoulou et al., 2009; Rontani et al., 2009). Consequently, degradation products of $\Delta^{5}$-sterols constitute excellent biomarkers for tracing diagenetic transformations of specific organisms (Mackenzie et al., 1982). Using these tracers to evaluate the relative influence of different degradation processes requires that their removal rate (by further degradation) is comparable to that of the parent $\Delta^{5}$-sterol. Although each sterol and its degradation products may be potentially totally mineralized by marine bacteria, we assume that they should exhibit similar reactivity towards bacterial degradation. This assumption is based on the fact that aerobic biodegradation of sterols generally involves initial attack on the side chain, which is similar in all the degradation tracers selected to that of the corresponding parent $\Delta^{5}$-sterol. Moreover, it may be noted that $3 \beta, 5 \alpha, 6 \beta$-steratriols, employed for autoxidation estimates are weakly affected by abiotic degradation processes. This is also the case for $\Delta^{4}-6 \alpha / \beta$-hydroperoxysterols (photo-oxidation tracers), which are much more stable than $\Delta^{5}-7 \alpha / \beta$ - and $\Delta^{6}-5 \alpha$-hydroperoxysterols (Christodoulou et al., 2009). Indeed, $\beta$-scission of the alkoxyl radicals resulting from homolytic cleavage of $\Delta^{5}$-7-hydroperoxysterols and $\Delta^{6}$-5-hydroperoxysterols affords secondary and tertiary radicals, respectively, more stable than the primary radical resulting from the cleavage of $\Delta^{4}$-6-hydroperoxysterols (Christodoulou et al., 2009). Moreover, proton driven cleavage (Hock cleavage) of $\Delta^{5}$-7-hydroperoxysterols and $\Delta^{6}-5$ hydroperoxysterols involves a highly favored migration of vinyl group (Frimer, 1979), while only an unfavored migration of alkyl group is possible in the case of $\Delta^{6}-5$ hydroperoxysterols (Rontani et al., 2014a).

Aerobic bacterial hydrogenation may convert $\Delta^{5}$-sterols to $5 \alpha(\mathrm{H})$-stanols, $5 \alpha(\mathrm{H})$-stanones and ster-4-en-3-ones (Gagosian et al., 1982; De Leeuw and Baas, 1986; Wakeham, 1989). During the treatment undergone by our samples $\left(\mathrm{NaBH}_{4}\right.$ reduction), $5 \alpha(\mathrm{H})$-stanones and ster-4-en-3-ones are respectively converted in $5 \alpha(\mathrm{H})$-stanols and ster-4-en-3-ols; these compounds hence constitute useful markers of bacterial degradation of sterols. To evaluate the proportion of biological degradation of cholesterol, and to better trace human impacts on the OM found in the Rhône, we also included coprostanol and epicoprostanol in its biodegradation products. Sterol biodegradation percentages were estimated using Eq. (1a) and (1b). Coprostanol $(5 \beta(\mathrm{H})$-cholestan- $3 \beta$-ol) is a stanol that arises from the anaerobic microbial degradation of cholesterol in the digestive tracts of higher land mammals, including man (Martin et al., 1973). Epicoprostanol (5 $\beta(\mathrm{H})$ cholestan-3 $\alpha$-ol) is not a major sterol in human faeces, but it 
is often used as an indicator of sewage treatment (McCalley et al., 1981):

sitosterol biodegradation $\%=[$ sitostanol $] /[$ sitosterol $]$ $\times 100$

cholesterol biodegradation $\%=[$ cholestanol + coprostanol + epicoprostanol $] /[$ cholesterol $] \times 100$.

Free radical autoxidation yields mainly $\Delta^{5}-3 \beta, 7 \alpha / \beta$ hydroperoxides and in smaller quantities 5,6-epoxysterols and $3 \beta, 5 \alpha, 6 \beta$-trihydroxysterols. $3 \beta, 5 \alpha, 6 \beta$-trihydroxysterols were chosen as tracers of autoxidation (Christodoulou et al., 2009; Rontani et al., 2009) and the sterol autoxidation percentage was estimated using Eq. (2) based on autoxidation rate constants calculated by Morrissey and Kiely (2006):

sterol autoxidation $\%=([3 \beta, 5 \alpha, 6 \beta-$ trihydroxysterols $]$

$\times 2.4) /[$ sitosterol or cholesterol $] \times 100$.

${ }^{1} \mathrm{O}_{2}$-mediated photo-oxidation (Type II photoprocesses) yields mainly $\Delta^{6}-5 \alpha$-hydroperoxides and to a lower extent $\Delta^{4}-3 \beta, 6 \alpha / \beta$-hydroperoxides. $\Delta^{6}-5 \alpha$-hydroperoxides are unstable and are converted very easily to the nonspecific 7-hydroperoxides, so they were discarded as markers of photo-oxidation. Although produced in lesser amounts, $\Delta^{4}-3 \beta, 6 \alpha / \beta$-hydroperoxides, which are relatively stable and highly specific, have been chosen as tracers of photooxidation processes and quantified after $\mathrm{NaBH}_{4}$ reduction to the corresponding diols. The percentage of sterol photooxidation was estimated using Eq. (3) (Christodoulou et al., $2009)$, based on the ratio $\Delta^{4}-6 \alpha / \beta$-hydroperoxides $/ \Delta^{6}-5 \alpha$ hydroperoxides found in biological membranes (0.30) (Korytowski et al., 1992):

sterol photo - oxidation $\%=$

([ $\Delta^{4}-3 \beta, 6 \alpha / \beta$-dihydroxysterol]

$\times(1+0.3) / 0.3) /[$ sitosterol or cholesterol $] \times 100$.

Here, values are expressed in proportions relative to the amount of remaining parent sterol in the sample. A total percentage of over $100 \%$ hence only means that degradation products were present in larger quantities than their associated parent sterol.

The results of the evaluation of sitosterol and cholesterol degradation processes are shown in Fig. 5. The most highly degraded samples sitosterol-wise were the ones from 18 July 2011, 26 June 2012 and 22 January 2013. Interestingly, cholesterol degradation shows a completely different trend. When looking at the type of degradation undergone by $\Delta^{5}$-sterols, it also appears clearly that, if autoand photo-oxidation processes are the major drivers of sitosterol oxidation, biodegradation is the major player in cholesterol degradation. Hedges and Keil (1995) hinted that sterols

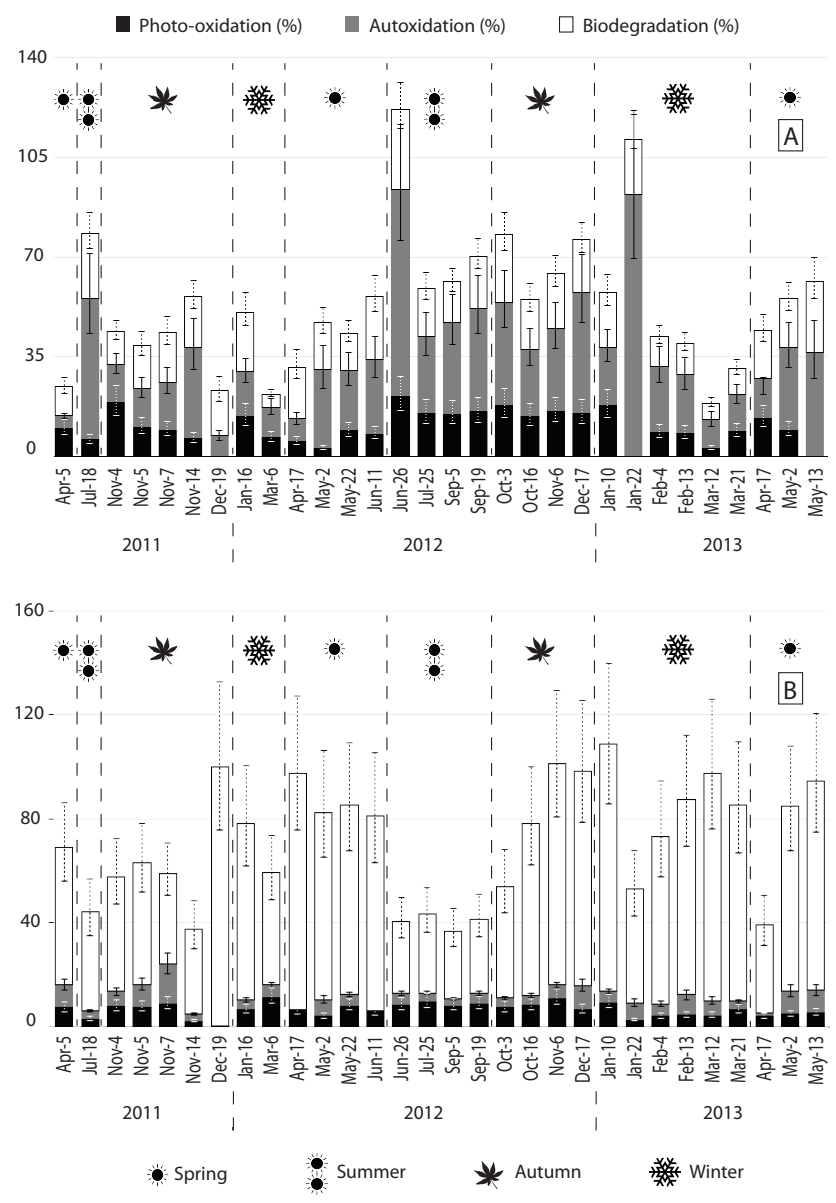

Figure 5. Biotic and abiotic degradation of sitosterol (a) and cholesterol (b) in the different samples. Full error shown here incorporates the $14 \%$ analytical standard error estimated for lipid quantification for all terms of the equations used. Sitosterol and cholesterol clearly have very different degradation patterns.

associated with waxy higher plant material might not be as prone to enzymatic degradation as other sterols, which would explain why sitosterol is only weakly biodegraded in our samples. Indeed, even though we showed that sitosterol is also produced during spring phytoplanktonic blooms, it is mainly derived from higher plants in most of the samples investigated. The dominance of coprostanol relative to cholestanol attests to a strong contribution of human or animal faeces to the cholesterol present in the Rhône River. Here we used two different ratios in order to better understand how human activities and wastewaters affect the Rhône waters. The first ratio, used to determine if waters are affected by waste water inputs and runoff has been previously used by Writer et al. (1995), and is calculated as follows: coprostanol / (cholesterol + cholestanol). These authors have defined a threshold of 0.06 above which samples are considered affected by wastewater inputs and runoff from pastures and feedlots, and below which they can be considered pristine. The second ratio is the epicoprostanol : coprostanol ratio 
proposed by Mudge and Seguel (1999), in order to illustrate the level of treatment undergone by wastewaters. The higher the ratio, the more treated the waters are, as epicoprostanol is only present in traces in primary sludge, while it is present in much higher quantities in treated sludge (McCalley et al., 1981). Both ratios are represented in Fig. 6 and they show that the Rhône is undeniably affected by wastewaters and, to a much lower extent given the historical land use around the Rhône, pasture runoff. However, we noted that both the ratio and the threshold used are unofficial and in no way are proof of a large-scale contamination or pollution. We only highlight here the non-pristine state of the Rhône waters, which is logical given the level of urbanization along the river. The epicoprostanol: coprostanol ratio also shows fluctuations in the level of treatment of wastewaters, and fluctuates with flow rates and precipitation levels.

During senescence, unsaturated higher plant lipids (and notably $\Delta^{5}$-sterols) may be photodegraded (type II photooxidation), with chlorophyll acting as a sensitizer (Rontani et al., 1996). Sitosterol present in higher plant phytodetritus should thus have been intensely photodegraded on land. However, the photo-oxidation rate estimates appeared to be relatively low compared to that of autoxidation and biodegradation (Fig. 5a). This is probably due to an intense free-radical-driven breakdown of hydroperoxides produced during photo-oxidation (Rontani et al., 2003). The photooxidation percentages displayed here are thus certainly underestimated.

The presence of large amounts of 24-ethylcholestan$3 \beta, 5 \alpha, 6 \beta$-triol in most of the samples indicates that autoxidation plays an important role in the degradation of sitosterol (Fig. 5a). Autoxidation (spontaneous free radical reaction of organic compounds with $\mathrm{O}_{2}$ ), which has been largely ignored until now in the environment, seems to play a key role in the degradation of sitosterol (Fig. 5a) and thus of higher plant material carried by the Rhône River. This assumption was well supported by the detection of significant proportions of compounds deriving from betulin autoxidation (data not shown). Recently, it has been demonstrated that autoxidation plays a key role in the degradation of terrestrial (Rontani et al., 2014b) and marine (Rontani et al., 2014a) vascular plant debris in seawater. There is clearly a growing body of evidence suggesting that autoxidation reactions can strongly impact the preservation of particulate organic matter in the environment and should be considered carefully alongside other removal processes such as biodegradation when constructing carbon cycles and evaluating carbon budgets. The lowest autoxidation rates observed in samples from 6 March 2012 and 12 March 2013 may be attributed to the phytoplanktonic bloom events, with high inputs of fresh material. While there is variability in the amount and type of degradation undergone by sterols in the sampled particulate matter, it is evident that sitosterol and cholesterol behave very differently when being degraded.

\subsubsection{Unsaturated fatty acids and cuticular waxes}

Fatty-acid sensitivity to photo- and autoxidation is intrinsically linked to their number of double bonds (Frankel, 1998), and we will only be looking at unsaturated fatty acids here. Unfortunately, oxidation products of polyunsaturated fatty acids (PUFA) are not stable enough to be used to monitor PUFA degradation. In contrast, photo- and autoxidation products of mono-unsaturated fatty acids (allylic hydroperoxyacids) are much more stable, and can be used (after $\mathrm{NaBH}_{4}$-reduction to the corresponding hydroxyacids) as tracers of the abiotic oxidation processes affecting POM (Marchand and Rontani, 2001). Free-radical-mediated oxidation (autoxidation) processes can be easily discriminated against photo-oxidation processes thanks to the specific allylic hydroperoxyacids specifically produced by autoxidative processes (Marchand and Rontani, 2001).

Samples only displayed small amounts of oxidation products of oleic acid (not quantified), probably due to the fact that unsaturated fatty acids and their degradation products are very labile and easily metabolized by bacteria (Marchand et al., 2005). Despite this degradation, the profiles obtained by GC-MS (exhibiting relatively high proportions of cis oxidation products) allowed us to confirm the important role played by autoxidation in the degradation of POM in the Rhône River. Cutin is present in $\mathrm{cu}-$ ticles covering all aerial parts of higher plants. It is constituted of biopolyesters mainly composed of hydroxy fatty acids. Long-chain $n$-alkanoic, $\omega$-hydroxy, dihydroxy, trihydroxy and epoxy-hydroxy acids constitute the major aliphatic monomers (Kolattukudy, 1980). It was previously demonstrated that Type II photo-oxidation processes act on some unsaturated cutin monomers such as $\omega$-hydroxyoctadec-9enoic acid ( $\omega$-hydroxyoleic acid) during the senescence of higher plants (Rontani et al., 2005). ${ }^{1} \mathrm{O}_{2}$ reacts with the carbon-carbon double bond, and leads to the formation of a hydroperoxide at each unsaturated carbon. Due to the involvement of allylic rearrangements, Type II photosensitized oxidation of $\omega$-hydroxyoleic acid results (after $\mathrm{NaBH}_{4}$-reduction of hydroperoxides to the corresponding alcohols) in the formation of isomeric allylic 18,(811)-dihydroxyoctadecanoic acids, with a trans double bond. These compounds constitute interesting specific tracers of higher plant material photo-oxidation. Autoxidation of this compound was never studied, but by analogy with oleic acid oxidation the autoxidative formation of specific cis allylic hydroperoxyacids was expected.

Significant amounts of allylic 18,(8-11)-dihydroxyoleic acid, with cis and trans double bonds have been effectively detected in some (not all) samples analyzed attesting to the involvement of auto- and photo-oxidation of higher plant material (Galeron and Rontani, unpublished data). The high proportions of cis isomers observed confirmed the dominance of autoxidation processes. Some samples (16 January 2012, 26 June 2012 and 18 July 2011) even displayed larger amounts 


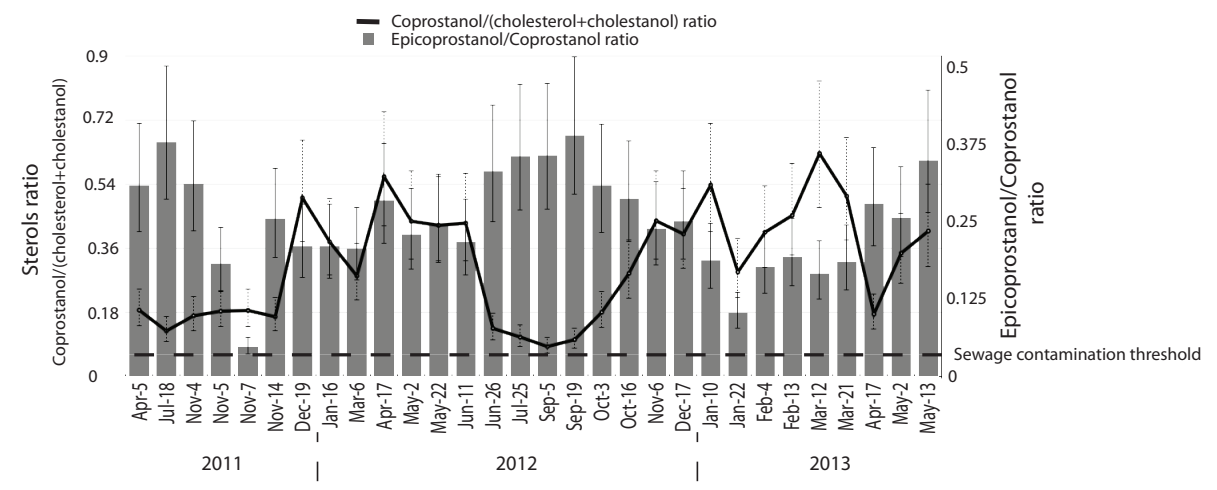

Figure 6. Coprostanol:(cholesterol+cholestanol) and epicoprostanol: coprostanol ratios of the different samples. Full error shown here incorporates the $14 \%$ analytical standard error estimated for lipid quantification for all terms of the ratios. Contamination threshold is 0.06 (See Sect. 3.3.2).

of oxidation products than $\omega$-hydroxyoleic acid, which evidences the importance of degradative processes on this compound. The previously discussed yearly variability in cuticular wax content in our samples (see Sect. 3.2.2 and Fig. 3b) explains some of these results.

\subsubsection{Hydroperoxide stability in SPM}

It was previously proposed that photochemically produced hydroperoxides could induce intense autoxidation processes in the marine environment (Rontani et al., 2014a). Hydroperoxides resulting from photo-oxidation processes may undergo: (1) heterolytic cleavage catalyzed by protons (Frimer, 1979) and (2) homolytic cleavage induced by transition metal ions (Pokorny, 1987) or UVR (Horspool and Armesto, 1992). Homolytic cleavage of hydroperoxides would lead to the formation of alkoxyl radicals, which can then: (1) abstract a hydrogen atom from another molecule to give alcohols, (2) lose a hydrogen atom to yield ketones, or (3) undergo $\beta$-cleavage reactions affording volatile products. During the $\mathrm{NaBH}_{4}$-reduction, hydroperoxides and ketones were reduced to the corresponding alcohols. The sum of the corresponding hydroperoxides, ketones and alcohols was evaluated under the form of alcohols. Application of a different treatment allowed us to specifically quantify hydroperoxides, alcohols and ketones (remaining in cuticular waxes, phytol, oleic acid, sitosterol and cholesterol oxidation products) (Fig. 7).

Clearly, the proportion of remaining hydroperoxides was highest in the case of sterols, with 49.4 and $31.3 \%$ respectively for 3,6- and 3,7-diols of sitosterol, and 51.5 and $33.5 \%$ for 3,6- and 3,7-diols of cholesterol, against less than $20 \%$ $(17.3 \%)$ for cutins, $12.0 \%$ for oleic acid, and $6.6 \%$ for phytol. Standard error was calculated based on all the results obtained $($ standard error $=$ standard deviation $/ \sqrt{ }(n)$ for $n$ samples). These results clearly indicate that despite the involvement of an intense free radical oxidation (autoxidation) inducing homolytic cleavage of peroxy bonds, a significant proportion of hydroperoxides is still intact in POM of the

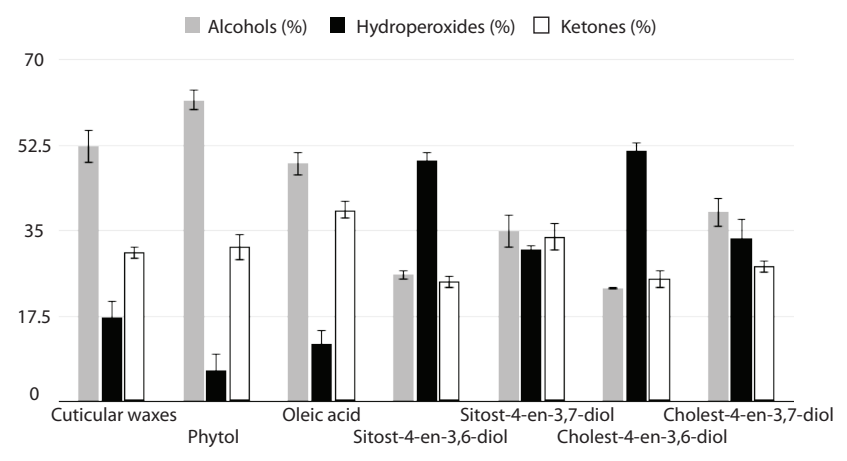

Figure 7. Relative percentages of intact hydroperoxides and their ketonic and alcoholic degradation products measured in the case of $\omega$-hydroxyoleic (cuticular waxes) and oleic acids, phytol, sitosterol and cholesterol oxidation products. Standard error was calculated based on the results obtained for all samples.

Rhône River. This proportion reaches $10 \%$ of the parent residual compound in the case of sitosterol and $5 \%$ in the case of cholesterol. Probably due to high compartmentalization effects, preservation of these compounds seems to be enhanced in higher plant debris. It was recently proposed that homolytic cleavage of photochemically produced hydroperoxides in riverine POM could be catalyzed by some redoxactive metal ions released from SPM in the mixing zone of riverine and marine waters (Rontani et al., 2014b). Due to the presence of significant amounts of hydroperoxides in higher plant residues, the involvement of intensive autoxidation of this material in the Rhône estuary is thus likely.

\section{Conclusions}

Based on a 2-year study of the particulate organic matter content of the Rhône River, the main freshwater supplier to the Mediterranean Sea, lipid analyses evidenced a strong contribution from terrestrial vascular plants, most no- 
tably gymnosperms. Phytoplanktonic cyclical inputs were also observed and identified as seasonal blooms. The observed amounts of sterols of diatom origin and steep drops in silica observed at the time of the blooms led us to suspect diatoms to be major contributors. Specific compounds like suberin markers, coprostanol and epicoprostanol allowed us to identify anthropic impacts on POM composition (paper mill discharging wastewater and treated wastewater discharge).

Using specific lipidic degradation products, we were able to identify for the first time the part that bacterial degradation, autoxidation and photo-oxidation play in organic matter degradation in a Mediterranean river. The study of lipid oxidation products showed that autoxidation, which has been largely underestimated until now in the environment, plays a major role in the degradation of plant-derived organic matter: autoxidation-produced degradation products are nearly half as important as the remaining amount of sitosterol $(25 \%$ on average across all samples), while biodegradation-produced compounds only represent about a quarter $(15 \%$ on average across all samples). Photo-oxidation degradation products, although probably underestimated, only stand at $10 \%$ (on average across all samples) of the remaining sitosterol amounts. While autoxidation processes appeared to play only a minor role during the degradation of sitosterol in the cold Mackenzie River (Arctic) (Rontani et al., 2014b), it is worth questioning the role that temperature plays in OM degradation, and wondering if it influences one degradation process over the others: do the temperatures found in the Rhône River, warmer than those of the Mackenzie, favor autoxidation? However, the low autoxidation state in the Mackenzie River could also be attributed to the presence of significant proportions of fresh sitosterol-producing phytoplanktonic species (Tolosa et al., 2013). Due to the lack of specificity of this sterol, it is clear that identification of autoxidation products of more specific tracers (such as betulin or amyrins) is absolutely necessary to monitor the degradation of higher plant material in rivers and oceans more precisely.

We also noted that cholesterol offers a very different degradation profile, undergoing little autoxidation, but mainly influenced by biotic degradation processes. Cholesterol is non-specific and can come from a number of sources, which is why it is not used as a tracer of the origin or the general degradation state of POM. However, its bacterial degradation products, including coprostanol and epicoprostanol, are good markers of sewage contamination and sewage treatment, and clearly indicated here that the Rhône waters were affected by wastewaters.

Finally, we have shown that even through the degradative processes impacting the TPOM flowing down the Rhône, there is still an important quantity of hydroperoxides remaining in the OM, which in turn should favor autoxidation upon the OM arrival at sea.
Acknowledgements. This work is a contribution to the Labex OTMed (no. ANR-11-LABX-0061) funded by the French Government "Investissements d'Avenir" program of the French National Research Agency (ANR) through the A*MIDEX project (no. ANR11-IDEX-0001-02). It was also supported by the LEFE-CYBER (Les Enveloppes Fluides et l'Environnement) national program, as part of the MORTIMER (Matière ORganique Terrestre rejetée par les fleuves et les rIvières en MER) research program. It was undertaken as part of the transversal research axis DEBAT of the Mediterranean Institute of Oceanography, Marseille, France.

Additional data were provided by "MOOSE" (Mediterranean Oceanic Observing System for the Environment) with the support of the "Agence de l'Eau Rhône-Méditerranée-Corse". Special thanks to Michel Fornier for providing samples.

Edited by: B. A. Bergamaschi

\section{References}

AGRESTE: En Provence-Alpes-Côte d'Azur, la forêt est sous-exploitée (Rapport du Ministère de l'agriculture, de l'alimentation, de la pêche, de la ruralité et de l'aménagement du territoire), 2011.

Amelung, W., Brodowski, S., Sandhage-Hofmann, A., and Bol, R.: Chapter 6 Combining Biomarker with Stable Isotope Analyses for Assessing the Transformation and Turnover of Soil Organic Matter, in: Advances in Agronomy, edited by: Sparks D. L., Academic Press, 155-250, 2008.

Aminot, A. and Kérouel, R.: Dosage automatique des nutriments dans les eaux marines: méthodes en flux continu (Editions Quae), 2007.

Atlas, R. M. and Bartha, R.: Hydrocarbon Biodegradation and Oil Spill Bioremediation, in: Advances in Microbial Ecology, edited by: Marshall K. C., Springer US, 287-338, 1992.

Bourbonniere, R. A. and Meyers, P. A.: Sedimentary geolipid records of historical changes in the watersheds and productivities of Lakes Ontario and Erie, Limnol. Oceanogr., 41, 352-359, 1996.

Bourgeois, S., Pruski, A. M., Sun, M.-Y., Buscail, R., Lantoine, F., Kerhervé, P., Vétion, G., Rivière, B., and Charles, F.: Distribution and lability of land-derived organic matter in the surface sediments of the Rhône prodelta and the adjacent shelf (Mediterranean Sea, France): a multi proxy study, Biogeosciences, 8, 3107-3125, doi:10.5194/bg-8-3107-2011, 2011.

Brown, R. C. and Wade, T. L.: Sedimentary coprostanol and hydrocarbon distribution adjacent to a sewage outfall, Water Res., 18, 621-632, 1984.

Cloern, J. E., Canuel, E. A., and Harris, D.: Stable carbon and nitrogen isotope composition of aquatic and terrestrial plants of the San Francisco Bay estuarine system, Limnol. Oceanogr., 47, 713-729, 2002.

Christodoulou, S., Marty, J.-C., Miquel, J.-C., Volkman, J. K., and Rontani, J.-F.: Use of lipids and their degradation products as biomarkers for carbon cycling in the northwestern Mediterranean Sea, Mar. Chem., 113, 25-40, 2009.

Conner, A. H., Nagasampagi, B. A., and Rowe, J. W.: Terpenoid and other extractives of western white pine bark, Phytochemistry, 19, 1121-1131, 1980. 
Cuny P. and Rontani J.-F.: On the widespread occurrence of 3methylidene-7,11,15-trimethylhexadecan-1,2-diol in the marine environment : a specific isoprenoid marker of chlorophyll photodegradation, Mar. Chem., 65, 155-165, 1999.

Cuny, P., Romano, J.-C., Beker, B., and Rontani, J.-F.: Comparison of the photodegradation rates of chlorophyll chlorin ring and phytol side chain in phytodetritus: is the phytyldiol versus phytol ratio (CPPI) a new biogeochemical index, J. Exp. Mar. Biol. Ecol., 237, 271-290, 1999.

Dachs, J., Bayona, J. M., Fowler, S. W., Miquel, J.-C., and Albaigés, J.: Evidence for cyanobacterial inputs and heterotrophic alteration of lipids in sinking particles in the Alboran Sea (SW Mediterranean), Mar. Chem., 60, 189-201, 1998.

De Leeuw, J. W. and Baas, M.: Early-stage diagenesis of steroids, Meth. Geoch., 24, 101-123, 1986.

De Leeuw, J. W. and Largeau, C.: A Review of Macromolecular Organic Compounds That Comprise Living Organisms and Their Role in Kerogen, Coal, and Petroleum Formation, in: Org. Geochem., edited by: Engel M. H., and Macko S. A., (Springer US), 23-72, 1993.

Diefendorf, A. F., Freeman, K. H., Wing, S. L., and Graham, H. V.: Production of $n$-alkyl lipids in living plants and implications for the geologic past, Geochim. Cosmochim. Ac., 75, 7472-7485, 2011.

Eyrolle, F., Radakovitch, O., Raimbault, P., Charmasson, S., Antonelli, C., Ferrand, E., Aubert, D., Raccasi, G., Jacquet, S., and Gurriaran, R.: Consequences of hydrological events on the delivery of suspended sediment and associated radionuclides from the Rhône River to the Mediterranean Sea, J. Soils Sediments, 12, 1479-1495, 2012.

Fine, P. M., Cass, G. R., and Simoneit, B. R. T.: Chemical Characterization of Fine Particle Emissions from Fireplace Combustion of Woods Grown in the Northeastern United States, Environ. Sci. Technol., 35, 2665-2675, 2001.

Foote, C. S.: Photosensitized oxidation and singlet oxygen: consequences in biological systems, NATO ASI 3 High Tech., 2, 85133, 1976.

Frankel, E. N.: Lipid oxidation, The Oily, Dundee, Scotland 129160, 1998.

Frimer, A. A.: The reaction of singlet oxygen with olefins: the question of mechanism, Chem. Rev., 79, 359-387, 1979.

Fruget, J.-F., Centofanti, M., Dessaix, J., Olivier, J.-M., Druart, J.C., and Martinez, P.-J.: Temporal and spatial dynamics in large rivers: example of a long-term monitoring of the middle Rhone River, Ann. Limnol. - Int. J. Lim., 37, 237-251, 2001.

Gagosian, R. B., Zafiriou, O. C., Peltzer, E. T., and Alford, J. B.: Lipids in aerosols from the tropical North Pacific: Temporal variability, J. Geophys. Res., 87, 11133-11144, 1982.

Gagosian, R. B., Nigrelli, G. E., and Volkman, J. K.: Vertical Transport and Transformation of Biogenic Organic Compounds from a Sediment Trap Experiment Off the Coast of Peru, Coastal Upwelling Its Sediment Record, edited by: Suess E., and Thiede J., Springer US, 241-272, 1983.

Hedges, J. I. and Keil, R. G.: Sedimentary organic matter preservation: an assessment and speculative synthesis, Mar. Chem., 49, 81-115, 1995.

Hedges, J. I., Keil, R. G., and Benner, R.: What happens to terrestrial organic matter in the ocean?, Org. Geochem., 27, 195-212, 1997.
Horspool, W. and Armesto, D.: Organic Photochemistry: A comprehensive treatment, Ellis Horwood, Prentice Hall: New York, 1992.

Jansson, M. B.: Land erosion by water in different climates, UNGI Rapport (Sweden), 1982.

Kolattukudy, P. E.: Cutin, suberin, and waxes, in: The Biochemistry of Plants, Vol. 4, Lipids: Structure and Function, edited by: Stumpf, P. K. and Conn, E. E., Academic Press Inc., New York, 571-645, 1980.

Korytowski, W., Bachowski, G. J., and Girotti, A. W.: Photoperoxidation of cholesterol in homogeneous solution, isolated membranes, and cells: comparison of the $5 \alpha$, and $6 \beta$ - hydroperoxides as indicators of singlet oxygen intermediacy, Photochem. Photobiol., 56, 1-8, 1992.

Kunst, L. and Samuels, A. L.: Biosynthesis and secretion of plant cuticular wax, Lipid Research, 42, 51-80, 2003.

Liu, J.: Pharmacology of oleanolic acid and ursolic acid, J. Ethnopharmacol., 49, 57-68, 1995.

Lorenzen, C. J.: Vertical distribution of chlorophyll and phaeopigments?: Baja California, Deep-Sea Res., 14, 735-745, 1967.

Ludwig, W., Dumont, E., Meybeck, M., and Heussner, S.: River discharges of water and nutrients to the Mediterranean and Black Sea: Major drivers for ecosystem changes during past and future decades?, Prog. Oceanogr., 80, 199-217, 2009.

Mackenzie, A. S., Brassell, S. C., Eglinton, G., and Maxwell, J. R.: Chemical fossils: the geological fate of steroids, Science, 217, 491-504, 1982.

Marchand, D. and Rontani, J.-F.: Characterisation of photooxidation and autoxidation products of phytoplanktonic monounsaturated fatty acids in marine particulate matter and recent sediments, Org. Geochem., 32, 287-304, 2001.

Marchand, D. and Rontani, J.-F.: Visible light-induced oxidation of lipid components of purple sulfur bacteria: a significant process in microbial mats, Org. Geochem., 34, 61-79, 2003.

Marchand, D., Marty, J.-C., Miquel, J.-C., and Rontani, J.-F.: Lipids and their oxidation products as biomarkers for carbon cycling in the northwestern Mediterranean Sea: results from a sediment trap study, Mar. Chem., 95, 129-147, 2005.

Martin, W. J., Subbiah, M. T. R., Kottke, B. A., Birk, C. C., and Naylor, M. C.: Nature of fecal sterols and intestinal bacterial flora, Lipids, 8, 208-215, 1973.

McCalley, D. V., Cooke, M., and Nickless, G.: Effect of sewage treatment on faecal sterols, Water Res., 15, 1019-1025, 1981.

McKee, B. A., Aller, R. C., Allison, M. A., Bianchi, T. S., and Kineke, G. C.: Transport and transformation of dissolved and particulate materials on continental margins influenced by major rivers: benthic boundary layer and seabed processes, Cont. Shelf Res., 24, 899-926, 2004.

Mendez-Millan, M., Dignac, M.-F., Rumpel, C., Rasse, D. P., and Derenne, S.: Dynamics of shoot vs. root $\mathrm{C}$ assessed by natural 13C abundance of their biomarkers, EGU General Assembly Conference Abstracts, p. 9968, 2010.

Meyers, P. A. and Ishiwatari, R.: Lacustrine organic geochemistry - an overview of indicators of organic matter sources and diagenesis in lake sediments, Org. Geochem., 20, 867-900, 1993.

Mihara, S. and Tateba, H.: Photosensitized oxygenation reactions of phytol and its derivatives, J. Org. Chem., 51, 1142-1144, 1986.

Morrissey, P. A. and Kiely, M.: Oxysterols: Formation and Biological Function, in: Advanced Dairy Chemistry Volume 2 Lipids, 
edited by: Fox, P. F., and McSweeney, P. L. H., Springer US, 641-674, 2006.

Mudge, S. M. and Seguel, C. G.: Organic Contamination of San Vicente Bay, Chile, Mar. Pollut. Bull., 38, 1011-1021, 1999.

Mueller, K. E., Polissar, P. J., Oleksyn, J., and Freeman, K. H.: Differentiating temperate tree species and their organs using lipid biomarkers in leaves, roots and soil, Org. Geochem., 52, 130$141,2012$.

Nelson, J. R.: Rates and possible mechanism of light-dependent degradation of pigments in detritus derived from phytoplankton, J. Mar. Res., 51, 155-179, 1993.

Nierop, K. G. J.: Origin of aliphatic compounds in a forest soil, Org. Geochem., 29, 1009-1016, 1998.

Nishimura, M. and Koyama, T. The occurrence of stanols in various living organisms and the behavior of sterols in contemporary sediments, Geochim. Cosmochim. Ac., 41, 379-385, 1977.

Novak, J. T. and Carlson, D. A.: The Kinetics of Anaerobic Long Chain Fatty Acid Degradation. J. Water Pollut. Con. F., 42, 19321943, 1970.

Otto, A., Shunthirasingham, C., and Simpson, M. J.: A comparison of plant and microbial biomarkers in grassland soils from the Prairie Ecozone of Canada, Org. Geochem., 36, 425-448, 2005.

Paper Excellence - Fibre Excellence Tarascon, available at: http:// www.paperexcellence.com/mills/fibre-excellence-tarascon/, last access: 14 April 2014.

Pokorny, J.: Major factors affecting the autoxidation of lipids, Autoxidation of Unsaturated Lipids, 141-206, 1987.

Ponomarenko, L. P., Stonik, I. V., Aizdaicher, N. A., Orlova, T. Y., Popovskaya, G. I., Pomazkina, G. V., and Stonik, V. A.: Sterols of marine microalgae Pyramimonas cf. cordata (Prasinophyta), Attheya ussurensis sp. nov. (Bacillariophyta) and a spring diatom bloom from Lake Baikal, Comp. Biochem. Phys. B, 138, 65-70, 2004.

Raimbault, P., Diaz, F., and Boudjellal, B.: Simultaneous determination of particulate forms of carbon, nitrogen and phosphorus collected on filters using a semi-automatic wet-oxidation procedure, Mar. Ecol. Progr. Ser., 180, 289-295, 1999.

Raimbault, P., Lantoine, F., and Neveux, J.: Dosage rapide de la chlorophylle $a$ et des phéopigments a par fluorimétrie après extraction au méthanol, Comparaison avec la méthode classique d'extraction à l'acétone, Océanis, 30, 189-205, 2004.

Rampen, S. W., Abbas, B. A., Schouten, S., and Damsté, J. S. S.: A comprehensive study of sterols in marine diatoms (Bacillariophyta): Implications for their use as tracers for diatom productivity, Limnol. Oceanogr., 55, 91-105, 2010.

Razboršek, M. I., Vončina, D. B., Doleček, V., and Vončina, E.: Determination of Oleanolic, Betulinic and Ursolic Acid in Lamiaceae and Mass Spectral Fragmentation of Their Trimethylsilylated Derivatives, Chroma, 67, 433-440, 2008.

Rontani, J.-F.: Photo-and free radical-mediated oxidation of lipid components during the senescence of phototrophic organisms, Senescence, Intech, Rijeka, 3-31, 2012.

Rontani, J.-F., Cuny, P., and Grossi, V.: Photodegradation of chlorophyll phytyl chain in senescent leaves of higher plants, Phytochemistry, 42, 347-351, 1996.

Rontani, J.-F., Rabourdin, A., Marchand, D., and Aubert, C.: Photochemical oxidation and autoxidation of chlorophyll phytyl side chain in senescent phytoplanktonic cells: Potential sources of several acyclic isoprenoid compounds in the marine environment, Lipids, 38, 241-254, 2003.

Rontani, J.-F., Rabourdin, A., Pinot, F., Kandel, S., and Aubert, C.: Visible light-induced oxidation of unsaturated components of cutins: a significant process during the senescence of higher plants, Phytochemistry, 66, 313-321, 2005.

Rontani, J.-F., Zabeti, N., and Wakeham, S. G.: The fate of marine lipids: Biotic vs. abiotic degradation of particulate sterols and alkenones in the Northwestern Mediterranean Sea, Mar. Chem., 113, 9-18, 2009.

Rontani, J.-F., Zabeti, N., and Wakeham, S. G.: Degradation of particulate organic matter in the equatorial Pacific Ocean: Biotic or abiotic?, Limnol. Oceanogr., 56, 333-349, 2011.

Rontani, J.-F., Vaultier, F., and Bonin, P.: Biotic and abiotic degradation of marine and terrestrial higher plant material in intertidal surface sediments from Arcachon Bay (France): A lipid approach, Mar. Chem., 158, 69-79, 2014a.

Rontani, J.-F., Charriere, B., Sempéré, R., Doxaran, D., Vaultier, F., Vonk, J. E., and Volkman, J. K.: Degradation of sterols and terrigenous organic matter in waters of the Mackenzie Shelf, Canadian Arctic, Org. Geochem., 75, 61-73, 2014b.

Sempéré, R., Charrière, B., Van Wambeke, F., and Cauwet, G.: Carbon inputs of the Rhône River to the Mediterranean Sea: Biogeochemical implications, Global Biogeochem. Cy., 14, 669-681, 2000.

Sicre, M.-A., Paillasseur, J.-L., Marty, J.-C., and Saliot, A.: Characterization of seawater samples using chemometric methods applied to biomarker fatty acids, Org. Geochem., 12, 281-288, 1988.

Sicre, M.-A., Tian, R. C., Broyelle, I., and Saliot, A.: Aquatic distribution of 4-desmethyl sterols in the Chang Jiang Estuary, China, Mar. Chem., 42, 11-24, 1993.

Simpson, M. J., Otto, A., and Feng, X.: Comparison of solidstate carbon-13 nuclear magnetic resonance and organic matter biomarkers for assessing soil organic matter degradation, Soil Sci. Soc. Am. J., 72, 268-276, 2008.

Spikes, J. D., and Straight, R.: Sensitized Photochemical Processes in Biological Systems, Annu. Rev. Phys. Chem., 18, 409-436, 1967.

Taipale, S., Strandberg, U., Peltomaa, E., Galloway, A. W. E., Ojala, A., and Brett, M. T.: Fatty acid composition as biomarkers of freshwater microalgae: analysis of 37 strains of microalgae in 22 genera and in seven classes, Aquat. Microb. Ecol., 71, 165-178, 2013.

Tolosa, I., Fiorini, S., Gasser, B., Martín, J., and Miquel, J. C.: Carbon sources in suspended particles and surface sediments from the Beaufort Sea revealed by molecular lipid biomarkers and compound-specific isotope analysis, Biogeosciences, 10, 20612087, doi:10.5194/bg-10-2061-2013, 2013.

Van Dongen, B. E., Zencak, Z., and Gustafsson, Ö.: Differential transport and degradation of bulk organic carbon and specific terrestrial biomarkers in the surface waters of a sub-arctic brackish bay mixing zone, Mar. Chem., 112, 203-214, 2008.

Vernet, M.: Phytoplankton dynamics in the Barents Sea estimated from chlorophyll budget models, Polar Research, 10, 129-146, 1991.

Vivian, H.: Hydrological changes of the Rhône River. Historical Change of Large Alluvial Rivers: Western Europe, John Wiley \& Sons, New York, 57-77, 1989. 
Volkman, J. K.: A review of sterol markers for marine and terrigenous organic matter, Org. Geochem., 9, 83-99, 1986.

Volkman, J. K.: Sterols in microorganisms, Appl. Microbiol. Biotechnol., 60, 495-506, 2003.

Volkman, J. K., Smith, D. J., Eglinton, G., Forsberg, T. E. V., and Corner, E. D. S.: Sterol and fatty acid composition of four marine haptophycean algae, J. Mar. Biol. Assoc. UK, 61, 509-527, 1981.

Wakeham, S. G.: Reduction of stenols to stanols in particulate matter at oxic-anoxic boundaries in sea water, Nature, 342, 787-790, 1989.

Wakeham, S. G.: Lipid biomarkers for heterotrophic alteration of suspended particulate organic matter in oxygenated and anoxic water columns of the ocean, Deep-Sea Res., 42, 1749-1771, 1995.
Wakeham, S. G. and Canuel, E. A.: Degradation and Preservation of Organic Matter in Marine Sediments, in: Marine Organic Matter: Biomarkers, Isotopes and DNA, edited by: Volkman, J. K., Springer Berlin Heidelberg, 295-321, 2006.

Writer, J. H., Leenheer, J. A., Barber, L. B., Amy, G. L., and Chapra, S. C.: Sewage contamination in the upper Mississippi River as measured by the fecal sterol, coprostanol, Water Res., 29, 14271436, 1995. 